ISSN 0258-7122

Bangladesh J. Agril. Res. 33(3) : 391-397, September 2008

\title{
STUDIES ON FRUITING, BEARING HABIT AND FRUIT GROWTH OF JACKFRUIT GERMPLASM
}

\author{
M. A. ULLAH ${ }^{1}$ AND M.A. HAQUE ${ }^{2}$
}

\begin{abstract}
Studies on fruiting, bearing habit and fruit growth of jackfruit was carried out at orchard of Jackfruit Research Project, Department of Horticulture, Bangladesh Agricultural University (BAU), Mymensingh during the period from November 2000 to October 2001. Ten jackfruit germplasm of 13 years of age were selected for this study. Fruit bearing habit of jackfruit was cauliflorous i.e., fruits are borne on trunk and branches. The germplasm under study bore fruits on trunk, primary, secondary, tertiary, fourth, fifth and sixth branches of jackfruit trees. On an average, the maximum fruits were borne on primary branches (33.0\%) followed by those on trunk (31.5\%), secondary (12.3\%), and fourth branch (8.4\%), while it was the lowest on sixth branch $(2.0 \%)$. The growth pattern of fruit of jackfruit is characterized by single sigmoid curve. This is true when all aspects of measurements viz, length, diameter, circumference, weight, and volume of fruits; length, breadth, weight of bulb as well as seed were plotted against time from fruit set to haiwesting maturity.
\end{abstract}

Key Words: Bearing habit, fruit growth, jackfruit germplasm.

\section{Introduction}

Jackfruit is a national fruit of Bangladesh. It occupies an area of 27,530 hectares having annual production of 2,79,000 tons (BBS, 2004). Fruiting and bearing habit include percent and duration of fruit set, fruit set in different sections of plant. Fruit growth includes growth of whole fruit and its different parts in respect of weight, length, and width. Studies on fruit growth will help the jackfruit growers to determine the appropriate time of harvesting the fruit to be nod as vegetable and as ripe fruit. If the stigma of female spike is not developed properly and receptive at the time of dehiscence of anthers, the percentage of fruit set may he lower (Samaddar, 1985). Studies on fruiting, bearing habit and growth pattern also provide information for adjusting cultural management to increase the productivity. Research work on above aspects of jackfruit is limited in Bangladesh. Therefore, the study on fruiting, bearing habit and fruit growth was undertaken.

\footnotetext{
${ }^{1}$ Senior Scientific Officer, Regional Agricultural Research Station, BARI, Akbarpur, Moulvibazar, ${ }^{2}$ Professor, Department of Horticulture, BAU, Mymensingh, Bangladesh.
} 


\section{Materials and Method}

The study was conducted at the orchard of Jackfruit Research Project, Department of Horticulture, Bangladesh Agricultural University, Mymensingh during the period from November 2000 to October 2002. Ten jackfruit germplasm viz., J-07, J-10, J-14, J-19/1, J19/2, J-20, J-22, J-31/l, J-31/2, and J-65 were selected from the orchard for the study. The plants were healthy, about 13 years of age and received similar cultural treatments. The soil of orchard was silty loam under old Brahmaputra flood plain, fertile, well drained and slightly acidic having $\mathrm{pH}$ value of about 6.1.

\section{Percent fruit set}

Withering of all stigmas of female spike is the indication of fruit set. Total number of female spikes of a germplasm was counted. The total number of fruits were also counted just after set by visiting the orchard regularly during the fruit setting period. Percent set fruit was calculated as:

$$
\text { Total number of fruit set }=\frac{\text { Percent fruit set }}{\text { Total number of female spikes }}=x 100
$$

\section{Per cent fruit borne on different sections of plant}

Total number of mature fruits of each germplasm was counted and number of fruits on each sections (trunk, primary, secondary, tertiary, fourth, fifth, and sixth branch) were also recorded separately. Percent fruit borne on different section was calculated as follows:

Per cent fruit borne on a particular section $=\frac{\text { Total number of fruits on the section }}{\text { Total number of fruits on the germplasm }}=\mathrm{x} 100$

\section{Fruit growth}

The ellipsoid shaped fruits were included in this study, which was also of three types: soft, hard, and intermediate. Weight of fruit and its length, diameter and circumference were recorded at 15 days intervals upto harvesting to determine the growth of fruit, Thus in all 8 samples, representing 8 stages of fruit development from fruit set to maturity were taken from each germplasm to study the changes in morphological dimensions, weight and volume at each stage. Fruits used in the growth study were collected from germplasm J-07, J-10, and J14 from fruit set. 
Length of fruit was measured from base to the apex, breadth, and circumference at the widest part. All measurements were made in centimeters with vernier calliper and measuring tape. All the fruits employed for morphological measurements were also utilized for recording the weight and volume. Fruit volume was measured by water displacement method. Similar observation in respect of length, breadth, and weight were taken for bulb and seed in a similar way 15 days after fruit set to onwards by cutting the fruits.

\section{Results and Discussion}

\section{Period of fruit set and percent fruit set}

The jackfruit germplasm in the present study set fruits during the period from second week of January to last week of April (Table 1). It was found that there was wide variation in the period of fruit set among the germplasm. Germplasm J07 had the longest fruit setting period (85 days), which was followed by J-31/2 (78 days), J-30 (64 days) and J-20 (55 days), while J22 showed the shortest fruit setting period (23 days). The percent of fruit set of jackfruit germplasm varied from 68.75 to 100 with an average of 90.72. Germplasm J-07, J-l 1, J-14, and J19/l had the highest percentage of fruit set (100\%) followed by J-19/2 (98.04), J30 (95.24), and J-20 (88.87). Germplasm J-31/1 had the lowest percentage of fruit set (68.75). The lowest percentage of fruit set seems to be due to nonreceptivity and improper development of stigma. The percent fruit set observed in the present study was higher than the findings reported by Samaddar (1985) and Tessy et al. (1996), which were 83.33 and 75\%, respectively.

Table 1. Number of female spikes, period and duration of fruit set, percentage of fruit set in jackfruit germplasm.

\begin{tabular}{l|l|l|l|l|l}
\hline Germless & \multicolumn{1}{c}{$\begin{array}{c}\text { Total no. of female } \\
\text { spikes }\end{array}$} & $\begin{array}{c}\text { No. of } \\
\text { fruits set }\end{array}$ & $\begin{array}{c}\text { Period of fruit set } \\
\text { (Date) }\end{array}$ & $\begin{array}{c}\text { Duration } \\
\text { (days) }\end{array}$ & $\begin{array}{c}\text { Percent } \\
\text { fruit set }\end{array}$ \\
\hline J-07 & 33 & 33 & $13.1 .01-4.4 .01$ & 85 & 100 \\
$\mathrm{~J}-11-0$ & 40 & 40 & $24.2 .01-28.3 .01$ & 33 & 100 \\
$\mathrm{~J}-14 / 1$ & 26 & 26 & $2.2 .01-25.3 .01$ & 52 & 100 \\
$\mathrm{~J}-19 / 1$ & 8 & 8 & $18.01 .01-13.2 .01$ & 27 & 100 \\
$\mathrm{~J}-19 / 2$ & 251 & 50 & $8.3 .01-20.4 .01$ & 44 & 98.04 \\
$\mathrm{~J}-20$ & 18 & 16 & $18.2 .01-13.4 .01$ & 55 & 88.87 \\
$\mathrm{~J}-22$ & 8 & 7 & $20.2 .01-14.3 .01$ & 23 & 87.5 \\
$\mathrm{~J}-31 / 1$ & 16 & 11 & $15.1 .01-15.2 .01$ & 32 & 68.75 \\
$\mathrm{~J}-31 / 2$ & 18 & 14 & $31.1 .01-2.4 .01$ & 78 & 77.78 \\
$\mathrm{~J}-65$ & 29 & 25 & $4.2 .01-25.3 .01$ & 50 & 86.21 \\
\hline Mean & 24.7 & 23 & - & 47.9 & 90.715 \\
Range & $8-51$ & $8-50$ & - & $23-85$ & $68.75-100.00$ \\
Stdev & 13.897 & 14.476 & - & 20.819 & 10.966 \\
\hline
\end{tabular}




\section{Bearing habit of fruit on different sections of plant of jackfruit germplasm}

Fruit bearing habit of jackfruit is cauliflorous i.e., fruits are borne on trunk and branches. The germplasm under study bore fruits on trunk, primary, secondary, tertiary, fourth, fifth and sixth branches. On an average, the maximum number of fruits were borne on primary branches (33.0\%), followed by trunk (31.5\%), secondary (12.3\%), and fourth branch (8.4\%), while it was the lowest on sixth branch (2.0\%) (Table 2). However, there were some variation in fruit bearing habit of individual germplasm. Germplasm J-3 1/1 and J-22 bore fruit on trunk and primary branch only. Germplasm J-19/2 produced fruits on most of the sections (primary to six branches) of the plant except trunk. Haque (2005) reported that jackfruit bore fruit on trunk, primary, secondary, and tertiary branches. He also found that most of the fruits were borne on primary branch (45.7\%) followed by secondary branch (25.5\%), trunk (16.1\%) and least on tertiary branch (12.7\%). The present findings had some similarity with results of above author. The variation might be due to difference in genotypic characteristics.

Tab1e 2. Fruit borne on different sections of jackfruit germplasm.

\begin{tabular}{llllllll|l|l|l}
\hline Germplasm & Trunk & $\begin{array}{c}\text { Primary } \\
\text { branch }\end{array}$ & $\begin{array}{c}\text { Secondary } \\
\text { branch }\end{array}$ & $\begin{array}{c}\text { Tertiary } \\
\text { branch }\end{array}$ & $\begin{array}{c}\text { Fourth } \\
\text { branch }\end{array}$ & $\begin{array}{c}\text { Fifth } \\
\text { branch }\end{array}$ & $\begin{array}{c}\text { Sixth } \\
\text { branch }\end{array}$ & Total \\
\hline $\mathrm{J}-07$ & $9(32.1)$ & $8(28.5)$ & $5(17.9)$ & $1(3.6)$ & $5(17.9)$ & $0(0.0)$ & $0(0.0)$ & 28 \\
$\mathrm{~J}-10$ & $20(55.6)$ & $12(33.3)$ & $3(8.3)$ & $1(2.8)$ & $0(0.0)$ & $0(0.0)$ & $0(0.0)$ & 36 \\
$\mathrm{~J}-14 / 1$ & $4(16.7)$ & $14(58.3)$ & $6(25.0)$ & $0(0.0)$ & $0(0.0)$ & $0(0.0)$ & $0(0.0)$ & 24 \\
$\mathrm{~J}-19 / 1$ & $6(75.0)$ & $2(25.0)$ & $0(0.0)$ & $0(0.0)$ & $0(0.0)$ & $0(0.0)$ & $0(0.0)$ & 8 \\
$\mathrm{~J}-19 / 2$ & $0(0.0)$ & $11(24.4)$ & $3(6.7)$ & $5(11.1)$ & $9(20.0)$ & $13(28.9)$ & $4(8.9)$ & 45 \\
$\mathrm{~J}-20$ & $0(0.0)$ & $5(33.3)$ & $4(26.7)$ & $4(26.7)$ & $2(13.3)$ & $0(0.0)$ & $0(0.0)$ & 15 \\
$\mathrm{~J}-22$ & $0(0.0)$ & $7(100.0)$ & $0(0.0)$ & $0(0.0)$ & $0(0.0)$ & $0((0.0)$ & $0(0.0)$ & 7 \\
$\mathrm{~J}-31 / 1$ & $8(100.0)$ & $0(0.0)$ & $0(0.0)$ & $0(0.0)$ & $0(0.0)$ & $0(0.0)$ & $0(0.0)$ & 8 \\
$\mathrm{~J}-31 / 2$ & $7(87.5)$ & $1(12.5)$ & $0(0.0)$ & $0(0.0)$ & $0(0.0)$ & $0(0.0)$ & $0(0.0)$ & 8 \\
$\mathrm{~J}-65$ & $10(41.7)$ & $7(29.1)$ & $5(20.8)$ & $1(4.2)$ & $1(4.2)$ & $0(0.0)$ & $0(0.0)$ & 24 \\
\hline Mean & 6.4 & 6.7 & 2.6 & 1.2 & 1.7 & 1.3 & 0.4 & 20.3 \\
Range & $0-20$ & $0-14$ & $0-6$ & $0-5$ & $0-9$ & $0-13$ & $0-4$ & \\
Stdev & 5.800 & 4.518 & 2.289 & 1.720 & 2.865 & 3.900 & 1.200 & 12.657 \\
\hline
\end{tabular}

\section{Growth of fruit, bulb and seed of jackfruit}

Detailed study on fruit growth and development of jackfruit is scanty. Some preliminary studies have been done by Tessy et al. (1996) to observe the increase of fruit weight with time. In the present study, attempts have been made to study growth pattern of fruit, bulb, and seed of jackfruit. 


\section{Fruit growth}

It was observed that the average length of fruit increased rapidly upto 60 days after fruit set and then it decreased again (Fig. 1). But fruit diameter increased slowly upto 15 days after fruit set and then the rate of increase was rapid upto 45 days and again it slowed down. The circumference followed the same pattern as the length. At maturity, the average length, diameter and circumference attained by the fruit were $35 \mathrm{~cm}, 24 \mathrm{~cm}$, and $61 \mathrm{~cm}$, respectively, Morton. (1987) recorded average length and diameter of jackfruit as $20-90 \mathrm{~cm}$ and $15-50 \mathrm{~cm}$, respectively.

The changes in weight and volume were slower upto 15 days after fruit set. Thereafter, a rapid increase took place till 105 days. Later the rate of increase dropped appreciably and it continued till maturity (Approx. 120 days). At maturity, the average weight and volume attained by the fruits were $6200 \mathrm{~g}$ and 6431cc, respectively.

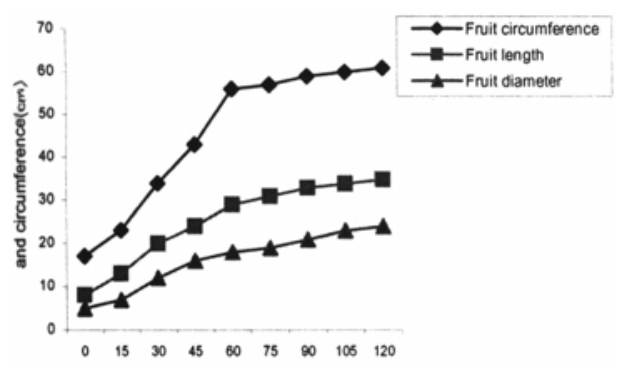

Days after fruit set

Fig. 1. Increase in fruit diameter, lenght and circum ference of jackfruit germplasm at 15 days interval.

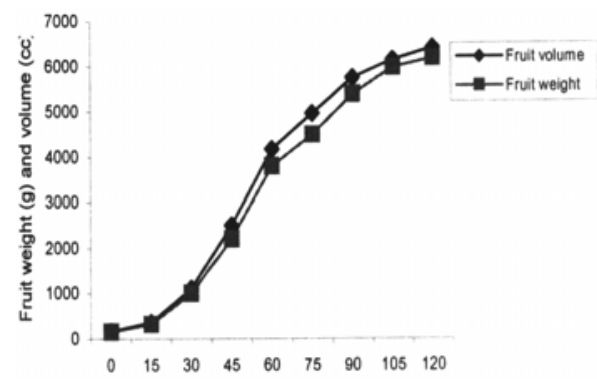

Days after fruit set

Fig. 2. Increase in fruit weight and volume of jackfruit gemplasm at 15 days interval.

\section{Bulb growth}

Length, breadth and weight of bulb of jackfruit germplasm were recorded at 15 days interval after fruit set. They increased rapidly from 15 days after fruit set to 90 days and subsequently slowed down till harvest (Fig. 3 and 4). Average increase in bulb weight also followed the similar trend as bulb length. At harvesting maturity, the average length and breadth attained by the bulb were 5.70 and $3.22 \mathrm{~cm}$ whereas the weight was $29 \mathrm{~g}$.

\section{Seed growth}

Measurements of seed were also recorded at 15 days from fruit set till maturity. The length and breadth of seed increased slowly from 15 to 30 days and they increased rapidly upto 60 days followed by a relatively slow rate of increase till 
maturity (Fig. 5 and 6). The rate of increase in seed weight was rapid from 15 days upto 60 days from fruit set. Then it was slower till maturity. At maturity, the average length and breadth attained by the seeds were 3.9 and $2.2 \mathrm{~cm}$, respectively, whereas the weight was $6 \mathrm{~g}$. Similar length and breadth of jackfruit was recorded by Jonathan et al. (2007).

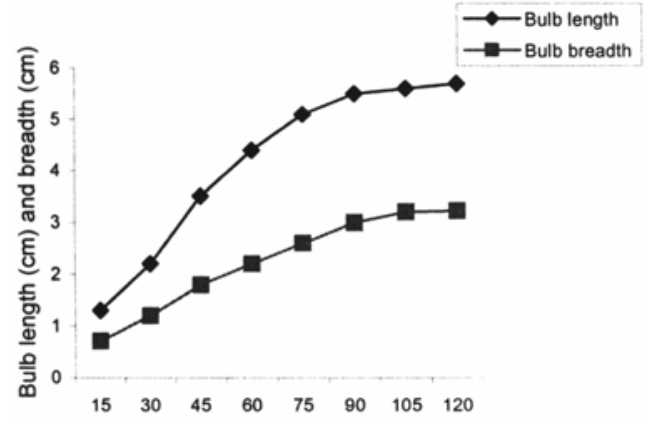

Days after fruit set

Fig. 3. Increase in bulb length and breadth of jackfruit germplasm at 15 days interval.

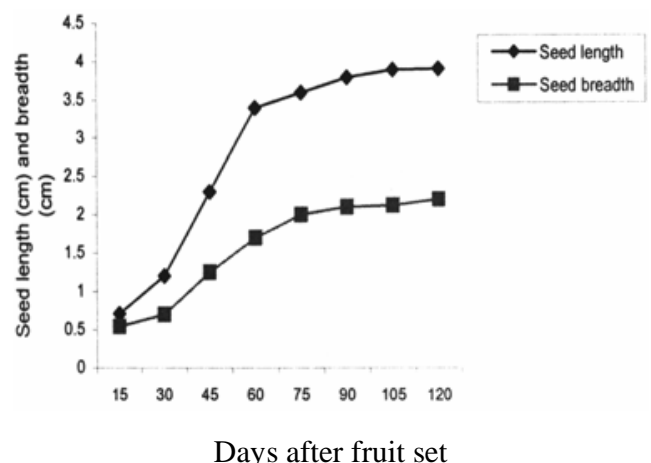

Fig. 5. Increase in seed lenght and breadth of jackfruit germplasm at 15 days interval.

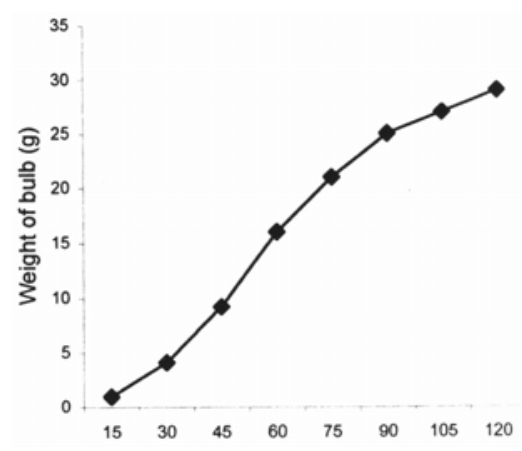

Days from fruit set

Fig. 4. Increase in bulb weight of jackfruit germplasm at 15 days interval.

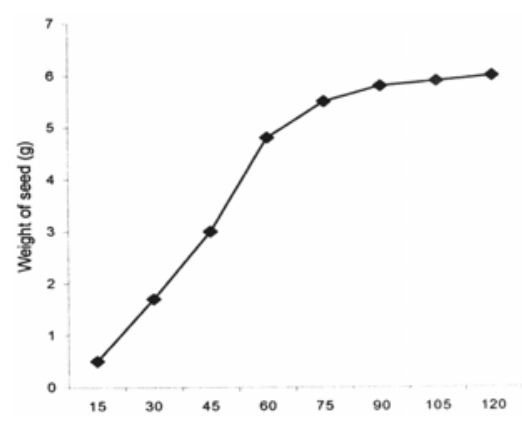

Days after fruit set

Fig. 6. Increase in seed weight of jackfruit germplasm at 15 days interval.

\section{Changes in morphological characters of bulb and seed at 15 days intervals}

The texture of pulp and seed changed with time. The pulp texture changed from soft to semi-hard from 15 to 30 days (Table 3). It turned hard after 45 days and remained so upto 105 days.. Again the bulbs were soft at ripe stage during 115120 days. The seeds were soft up to 45 days. Then they became semi-hard upto 75 days and became hard thereafter till they were ripe. From the above results, it is concluded that 45 to 75 days was the optimum time to use jackfruit as vegetable when the seeds were soft to semi-hard. 
Table 3. Changes in morphological characters of fruit, bulb and seed at $\mathbf{1 5}$ days intervals from fruit set of jackfruit.

\begin{tabular}{llllll}
\hline \multirow{2}{*}{$\begin{array}{c}\text { Days after } \\
\text { fruit set }\end{array}$} & \multicolumn{2}{c|}{ Colour of } & \multicolumn{2}{c}{ Texture of } \\
\cline { 2 - 5 } 15 & bulb & \multicolumn{1}{c}{ seed } & bulb & \multicolumn{1}{c}{ seed } \\
30 & White & White & Soft & Soft \\
45 & White & White & Semi-hard & Soft \\
60 & White & White & Hard & Soft \\
75 & Creamy white & Creamy white & Hard & Semi-hard \\
90 & Creamy white & Creamy white & Hard & Semi-hard \\
105 & Yellowish white & Light brown & Hard & Hard \\
120 & Yellowish white & Brown & Hard & Hard \\
\hline
\end{tabular}

The present investigation has shown that growth of fruit of jackfruit is characterized by simple sigmoid curve. This is true when all parameters of measurements viz., length, diameter, circumference, weight, and volume of fruit; length, breadth, weight of bulb as well as seed were plotted against time from fruit set to harvesting matuty. Tessy et al. (1996) also obtained a similar pattern of growth in jackfruit. A similar growth curve has also been reported for mango (Saini et al., 1971). The mango is botanically a simple fruit but showed same pattern of growth like jackfruit which is a multiple fruit.

\section{References}

BBS. 2004. Monthly Statistical Bulletin of Bangladesh, October 2004. Bangladesh Bureau of Statistics. Ministry of Planning, Government of the People's Republic of Bangladesh. p.48.

Haque M. A. 2005. Fruiting behaviour of jackfruit. J. Bangladesh Soc. Agric. Sci. Technol. 2(1\&2): 135-140.

Jonathan, H.C., C.F. Balerdi and I. Maguire. 2007. Jackfruit growing in the Florida home landscape. Downloaded from the web site: http:/Jedis.ifas.ufl.edu/MG370

Morton, J. 1987. Jackfruit. In: Fruits of warm climates. Downloaded from the web site: http://www.hort.purdue.edu/newcrop/rnorton/jackfruit_ars.htrn I

Saini, S.S., R. N. Singh and G. S. Paliwal. 1971. Studies on fruit set, growth and development in mango (Mangfera indica L.), Indian J. Hort. 28: 247-56.

Samaddar, H. N. 1985. Jackfruit varieties, flowering, floral biology, pollination, fruit set and fruit growth. In: Fruits of India, Naya Prakash, Calcutta 6, India, pp. 448-94.

Tessy, J., K. Kumaran and T. Joseph. 1996. Fruit set, fruit development and fruit drop in hard and soft flaked types of jack (Artocarpus heterophyllus Lam.). I. Tropical Agric. 34(1): 21-24. 